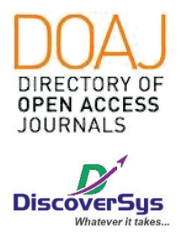

Published by DiscoverSys

\section{Analisis faktor risiko bayi Berat Badan Lahir Rendah (BBLR) di Unit Pelayanan Terpadu (UPT) Kesehatan Masyarakat (Kesmas) Gianyar I tahun 2016-2017}

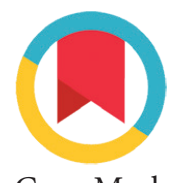

CrossMark

\author{
Padma Permana, ${ }^{1 *}$ Gede Bagus Rawida Wijaya ${ }^{1}$
}

\section{ABSTRACT}

Background: One of the major causes of newborn mortality is Low Birth Weight (LBW). Each year estimated $15 \%$ to $20 \%$ of world births or more than 20 million babies are LBW. In UPT Kesmas Gianyar I, there is an increasing trend of LBW incidence from 2014 to June 2017. So, this study aims to determine several risk factors associated with LBW at UPT Kesmas Gianyar I during 2016-2017 period.

Methods: A case-control analytic study was conducted among case group of LBW mothers and control group of mothers with normal weight babies in 2017. Selection technique of case group done by total sampling method, while control group by simple random sampling. Data were analysed using SPSS version 21 for Windows and showing in odds ratio, percentage, and p-value.
Results: A total of 106 respondens were enrolled in this study whereas each group consists of 53 patients. There was no significant relationship between mother's age, number of parity, anemia status, nutritional status, and distance of pregnancy with low birth weight incidence $(P>0.05)$. However, multiple pregnancy has shown a significant relationship with LBW (OR: 14.9; 95\% Cl 3.2-68.5; $\mathrm{P}=0.0001)$ as well as gestational age (OR: $3.1 ; 95 \% \mathrm{Cl} 1.02-9.50$; $\mathrm{P}=0.038$ ).

Conclusion: Mothers with multiple pregnancies have a 14.9 times risk of having a baby LBW as well as a premature gestational age also have a 3.1 times higher risk of delivering LBW infants.
'Mahasiswa Pendidikan Dokter, Fakultas Kedokteran, Universitas Udayana, Bali, Indonesia

\section{*Korespondensi:}

Padma Permana; Mahasiswa Pendidikan Dokter, Fakultas Kedokteran, Universitas Udayana, Bali, Indonesia; padma.permana@gmail.com

Diterima: 06-04-2019 Disetujui: 11-10-2019 Diterbitkan: 01-12-2019
Keywords: LBW, Risk Factors, Case Control

Cite This Article: Permana, P., Wijaya, G.B.R. 2019. Analisis faktor risiko bayi Berat Badan Lahir Rendah (BBLR) di Unit Pelayanan Terpadu (UPT) Kesehatan Masyarakat (Kesmas) Gianyar I tahun 2016-2017. Intisari Sains Medis 10(3): 674-678. D0I: 10.15562/ism.v10i3.481

\section{ABSTRAK}

Latar Belakang: Salah satu penyebab utama kematian bayi baru lahir adalah Berat Badan Lahir Rendah (BBLR). Setiap tahun diperkirakan 15\% hingga 20\% dari kelahiran dunia atau lebih dari 20 juta bayi adalah BBLR. Di UPT Kesmas Gianyar I, ada kecenderungan peningkatan kejadian BBLR dari 2014 hingga Juni 2017. Jadi, penelitian ini bertujuan untuk menentukan beberapa faktor risiko yang terkait dengan BBLR di UPT Kesmas Gianyar I selama periode 20162017.Metode: Sebuah studi analitik case-control dilakukan terhadap kelompok kasus ibu BBLR dan kelompok kontrol ibu dengan bayi berat normal pada tahun 2017. Teknik pemilihan kelompok kasus dilakukan dengan metode total sampling, sedangkan kelompok kontrol dengan simple random sampling. Data dianalisis menggunakan SPSS versi 21 untuk Windows dan ditampilkan dalam odds rasio, persentase, serta nilai-p.

Hasil: Sebanyak 106 responden terdaftar dalam penelitian ini dimana setiap kelompok terdiri dari 53 pasien. Tidak terdapat hubungan yang bermakna antara usia ibu, jumlah paritas, status anemia, status gizi, dan jarak kehamilan dengan kejadian berat lahir rendah ( $P>$ 0,05). Namun, kehamilan ganda telah menunjukkan hubungan yang bermakna dengan BBLR (OR: 14,9; 95\% IK 3,2-68,5; P =0,0001) maupun usia kehamilan (OR: 3,1; $95 \%$ IK 1,02-9,50; $P=0,038$ ).

Kesimpulan: Ibu dengan kehamilan ganda memiliki risiko 14,9 kali memiliki BBLR dimana usia kehamilan prematur juga memiliki risiko 3,1 kali lebih tinggi untuk melahirkan bayi BBLR.

Cite Pasal Ini: Permana, P., Wijaya, G.B.R. 2019. Analisis faktor risiko bayi Berat Badan Lahir Rendah (BBLR) di Unit Pelayanan Terpadu (UPT) Kesehatan Masyarakat (Kesmas) Gianyar I tahun 2016-2017. Intisari Sains Medis 10(3): 674-678. DOI: 10.15562/ism.v10i3.481

\section{PENDAHULUAN}

Angka kematian bayi merupakan salah satu target yang menjadi perhatian utama dari Millenium Development Goals pada tahun 2015. Angka kematian bayi masih tergolong tinggi di negara ASEAN yaitu sebesar 23 kasus per 1000 kelahiran. Sementara itu data kematian bayi (AKB) di Indonesia dinilai paling tinggi jika dibandingkan dengan negara ASEAN lainnya yaitu pada 2015 sebesar 22,23 per 1000 kelahiran hidup. Data ini masih belum mencapai target program dari WHO yaitu Sustainable Development Goals (SDGs) yang menargetkan AKB sekurang-kurangnya 12 per 1000 kelahiran hidup. 
Salah satu penyebab utama kematian bayi adalah berat badan lahir rendah (BBLR). ${ }^{1}$

Berdasarkan hasil pengumpulan data kesehatan provinsi yang berasal dari fasilitas pelayanan kesehatan, lima provinsi mempunyai presentase BBLR tertinggi adalah Provinsi Papua (27\%), Papua Barat $(23,8 \%)$, NTT $(20,3 \%)$, Sumatera Selatan $(19,5 \%)$, dan Kalimantan Barat (16,6\%). Sedangkan lima provinsi dengan presentase BBLR terendah adalah Bali $(5,8 \%)$, Sulawesi Barat (7,2\%), Jambi $(7,5 \%)$, Riau (7,6\%), dan Sulawesi Utara (7,9\%). Angka tersebut belum mencerminkan kondisi sebenarnya yang ada di masyarakat karena belum semua berat badan bayi yang dilahirkan dapat dipantau oleh petugas kesehatan, khususnya yang ditolong oleh dukun atau tenaga non-kesehatan lainnya. ${ }^{2}$

Bali tercatat sebagai daerah dengan presentase BBLR rendah, namun salah satu daerah di Bali yaitu Gianyar, melalui data yang didapatkan dari salah satu puskesmas, menunjukkan keadaan yang berbeda. Berdasarkan data yang didapatkan di UPT Kesmas Gianyar I terdapat tren peningkatan kejadian BBLR di wilayah kerja puskesmas ini dari tahun 2014 hingga Juni 2017 secara berturutturut sebagai berikut; 2,9\% (2014), 3,4\% (2015), 4,4\% (2016), dan 5,5\% (Juni 2017). Data-data ini menunjukan bahwa target prevalensi BBLR $<2 \%$ di UPT Kesmas Gianyar I tidak pernah tercapai dan justru dari tahun ke tahun kejadian BBLR semakin meningkat.

Berdasarkan pada permasalahan tersebut, maka penelitian ini bertujuaan untuk mencari tahu berbagai faktor yang berhubungan dengan resiko BBLR di UPT Kesmas Gianyar 1 selama periode tahun 2016-2017.

\section{METODE}

Pada penelitian ini digunakan data sekunder yang berasal dari rekam medis yang diambil dari bulan Juli sampai Agustus 2017. Desain studi kasus-kontrol (case-control) dipergunakan dalam studi ini. Sampel kelompok kasus pada penelitian ini merupakan seluruh bayi dengan BBLR yang tercatat di UPT Kesmas Gianyar I pada periode penelitian (Total sampling). Sementara itu sampel kelompok kontrol diambil dengan metode simple random sampling berdasarkan sampling frame ibu non-BBLR yang tercatat di register Sample frame kelompok kontrol tersebut kemudian dilakukan pemilihan secara random sejumlah yang sama dengan kelompok kasus. Pemilihan secara random ini dilakukan dengan menggunakan program Microsoft Excel 2013 dengan menggunakan fungsi $=$ RAND () untuk memberikan nomer secara acak pada masing-masing nomer rekam medis pada sampling frame kemudian diurutkan dari nilai random terkecil hingga terbesar. Lalu diambil sejumlah 53 nomer rekam medis dengan urutan nomer random terkecil untuk dijadikan kelompok kontrol.

Berbagai parameter faktor resiko yang dinilai pada studi ini kemudian dikelompokkan secara dikotom berdasarkan variabelnya masing-masing. Sedangkan variabel penelitian yang diteliti pada studi ini berhubungan dengan faktor resiko terjadinya BBLR meliputi usia ibu, jumlah paritas, status anemia, status gizi, jarak kehamilan, kehamilan ganda, dan usia gestasi. Data disampaikan dalam bentuk frekuensi dan persentase dimana kemudian dianalisis dengan piranti lunak SPSS versi 21 untuk Windows. Nilai P dikatakan bermakna apabila kurang dari 0,05 .

\section{HASIL}

Sebanyak 106 sampel berhasil dikumpulkan dengan rincian 53 kelompok kasus dan 53 kelompok kontrol. Hasil dari analisis faktor risiko ibu dengan kejadian BBLR dapat dilihat pada Tabel 1 berikut. Hasil menunjukkan bahwa kategori umur tidak beresiko dominan pada kelompok kontrol $(94,3 \%)$, begitu pula untuk status gizi non-KEK $(90,6 \%)$, tidak terdapat kehamilan ganda $(96,3 \%)$, dan aterm usia kehamilan (90,6\%). Sedangkan pada kelompok kasus sebagian besar responden berada pada kategori paritas tidak beresiko $(69,8 \%)$, tanpa status anemia $(90,6 \%)$, jarak kehamilan tidak beresiko (96,2\%), pendidikan ibu tinggi $(71,7 \%)$, dan pekerjaan ibu bukan ibu rumah tangga $(59,6 \%)$ (Tabel 1)

Dilihat dari faktor risiko bayi yaitu; 1) Kehamilan ganda, dan 2) Umur gestasi, ternyata didapatkan nilai $\mathrm{p}$ yang signifikan $(\mathrm{p}<0,05)$ yaitu variabel kehamilan ganda dengan OR(IK95\%): $14,9(3,2-68,5)$ dan variabel umur gestasi dengan OR(IK95\%): 3,1(1,02-9,50). Hasil ini menunjukan bahwa ibu dengan kehamilan ganda memiliki risiko melahirkan bayi BBLR 14,9 kali lebih tinggi dibandingkan ibu tanpa kehamilan ganda, sedangkan ibu yang melahirkan secara prematur memiliki risiko mehirkan bayi BBLR 3,1 kali lebih tinggi dibandingkan dengan ibu yang melahirkan secara aterm (Tabel 1).

Kemudian analisis faktor pekerjaan dan tingkat pendidikan ibu menunjukkan tidak terdapat variabel dengan nilai $\mathrm{p}<0,05$ oleh karena itu tidak terdapat faktor risiko lingkungan yang secara bermakna meningkatkan risiko kejadian BBLR di UPT Kesmas Gianyar 1. Hasil dari analisis faktor risiko tersebut dengan kejadian BBLR dapat dilihat pada Tabel 1 sebelumnya. 
Tabel 1 Analisis berbagai faktor resiko terhadap kejadian kasus BBLR

\begin{tabular}{|c|c|c|c|c|}
\hline Faktor Resiko & $\begin{array}{l}\text { Kasus } \\
\text { N (\%) }\end{array}$ & $\begin{array}{c}\text { Kontrol } \\
\text { N (\%) }\end{array}$ & $\begin{array}{c}\text { OR } \\
\text { (IK 95\%) }\end{array}$ & $\mathbf{P}$ \\
\hline \multicolumn{5}{|l|}{ Umur ibu } \\
\hline Berisiko & $6(11,3)$ & $3(5,7)$ & $2,1(0,5-8,9)$ & 0,292 \\
\hline Tidak berisiko & $47(88,7)$ & $50(94,3)$ & & \\
\hline \multicolumn{5}{|l|}{ Paritas } \\
\hline Berisiko & $16(30,2)$ & $23(43,4)$ & $0,5(0,2-1,2)$ & 0,150 \\
\hline Tidak berisiko & $37(69,8)$ & $30(56,6)$ & & \\
\hline \multicolumn{5}{|l|}{ Status Anemia } \\
\hline Iya & $5(9,4)$ & $7(13,2)$ & $0,6(0,2-2,3)$ & 0,540 \\
\hline Tidak & $48(90,6)$ & $46(86,8)$ & & \\
\hline \multicolumn{5}{|l|}{ Status gizi } \\
\hline KEK & $6(11,5)$ & $5(9,4)$ & $1,2(0,3-4,2)$ & 0,752 \\
\hline Non-KEK & $46(88,5)$ & $48(90,6)$ & & \\
\hline \multicolumn{5}{|l|}{ Jarak kehamilan } \\
\hline Berisiko & $2(3,8)$ & $3(5,7)$ & $0,65(0,1-4,0)$ & 0,647 \\
\hline Tidak berisiko & $51(96,2)$ & $50(94,3)$ & & \\
\hline \multicolumn{5}{|l|}{ Kehamilan Ganda } \\
\hline Ya & $19(36,5)$ & $2(3,7)$ & $14,9(3,2-68,5)$ & $0,0001^{\star}$ \\
\hline Tidak & $33(63,5)$ & $52(96,3)$ & & \\
\hline \multicolumn{5}{|l|}{ Umur Gestasi } \\
\hline Prematur & $13(24,5)$ & $5(9,4)$ & $3,1(1,02-9,5)$ & $0,038^{\star}$ \\
\hline Aterm & $40(75,5)$ & $48(90,6)$ & & \\
\hline \multicolumn{5}{|l|}{ Pendidikan ibu } \\
\hline Rendah & $15(28,3)$ & $16(30,2)$ & $0,91(0,39-2,10)$ & 0,830 \\
\hline Tinggi & $38(71,7)$ & $37(69,8)$ & & \\
\hline \multicolumn{5}{|l|}{ Pekerjaan ibu } \\
\hline Non-IRT & $31(59,6)$ & $31(57,4)$ & $0,68(0,46-2,10)$ & 0,954 \\
\hline IRT & $21(40,4)$ & $23(42,6)$ & & \\
\hline
\end{tabular}

KEK= Kurang Energi Kronis; OR=Odd Ratio; IK95\%=Interval Kepercayaan 95\%;

${ }^{*}=$ bermakna apabila nilai $\mathrm{P}<0,05$; IRT: ibu rumah tangga

\section{PEMBAHASAN}

Hasil penelitian ini menunjukkan bahwa tidak terdapat hubungan yang bermakna antara variabel umur ibu dengan kejadian BBLR di UPT Kesmas Gianyar 1. Hasil ini sesuai dengan penelitian yang dilakukan oleh Mahayana dkk dan Trihardiani dkk sebelumnya. ${ }^{3,4}$ Penelitian terdahulu menunjukkan bahwa pada ibu hamil dengan umur $<20$ tahun memiliki rahim dan panggul yang belum tumbuh mencapai ukuran dewasa. Akibatnya, ibu hamil pada umur ini sangat mungkin mengalami persalinan lama/macet, atau gangguan persalinan lainya karena ketidaksiapan ibu untuk menerima tugas dan tanggung jawabnya sebagai orang tua. Sedangkan pada umur $>35$ tahun, kesehatan ibu sudah menurun, akibatnya ibu hamil pada umur itu mempunyai kemungkinan lebih besar untuk mempunyai anak cacat, persalinan lama dan pendarahan. ${ }^{3,4}$

Kejadian BBLR lebih sering didapatkan pada ibu dengan jumlah paritas 1 dan lebih dari 4 karena terdapatnya jaringan parut akibat kehamilan dan persalinan terdahulu. Jaringan parut tersebut mengakibatkan persediaan darah ke plasenta tidak adekuat sehingga perlekatan plasenta tidak sempurna sehingga penyaluran nutrisi yang berasal dari ibu ke janin terganggu dan kurang mencukupi kebutuhan janin. Sedangkan kejadian BBLR pada ibu dengan paritas pertama disebabkan oleh masih minimnya pengalaman dan pengetahuan ibu hamil dalam menangani kehamilannya. ${ }^{3}$ Hal tersebut sesuai dengan hasil studi kami dimana tidak ditemukan hubungan bermakna antara jumlah 
paritas dengan kejadian BBLR di UPT Kesmas Gianyar 1. Hasil ini tidak sesuai dengan teori yang ada, namun sejalan dengan beberapa penelitian sebelumnya. ${ }^{5,6}$

Kadar hemoglobin darah sangat penting untuk kesehatan ibu dan bayi. Keadaan anemia akibat kadar hemoglobin yang rendah dapat menyebabkan distribusi oksigen ke jaringan akan berkurang dan akan menurunkan metabolisme jaringan sehingga pertumbuhan janin akan terhambat, dan mengakibatkan berat badan lahir bayi rendah. ${ }^{7}$ Hasil studi ini juga menunjukkan tidak terdapat hubungan yang bermakna antara variabel hemoglobin dengan kejadian BBLR di UPT Kesmas Gianyar 1. Hasil ini sejalan dengan penelitian sebelumnya oleh Yuliani, namun ada beberapa penelitian yang menunjukkan hasil berbeda. ${ }^{4,6,7}$ Perbedaan hasil ini dapat disebabkan karena pada penelitian ini hanya sedikit sekali terdapat ibu yang mengalami anemia. Masingmasing $5(9,4 \%)$ dan $7(13,2 \%)$ ibu dari kelompok kasus dan kontrol yang mengalami anemia. Prevalensi yang rendah ini menjadikan analisis $c h i$ square yang dilakukan juga tidak menunjukan nilai kemaknaan yang bermakna.

Terjadinya BBLR akibat Kekurangan Energi Kronik (KEK) pada ibu hamil diawali dengan ibu hamil yang menderita KEK yang menyebabkan volume darah dalam tubuh ibu menurun dan cardiac output ibu hamil tidak cukup, sehingga meyebabkan adanya penurunan aliran darah ke plasenta. Menurunya aliran darah ke plasenta menyebabkan dua hal yaitu berkurangnya transfer zat-zat makanan dari ibu ke plasenta yang dapat menyebabkan retardasi pertumbuhan janin dan pertumbuhan plasenta lebih kecil yang menyebabkan bayi dengan berat badan lahir rendah (BBLR). ${ }^{7}$

Pada penelitian ini hanya terdapat sedikit ibu yang mengalami KEK. Prevalensi yang rendah ini menjadikan analisis chi square yang dilakukan tidak menunjukan nilai kemaknaan yang bermakna dimana sejalan dengan beberapa penelitian sebelumnya., ${ }^{4,6,7}$

Jarak kehamilan ibu hamil sangat mempengaruhi berat bayi yang dilahirkan. Seorang ibu yang jarak kehamilannya dikatakan berisiko apabila hamil dalam jangka kurang dari dua tahun, dan hal ini jelas menimbulkan gangguan pertumbuhan hasil konsepsi, sering terjadi immaturitas, prematuritas, cacat bawaan, atau janin lahir dengan berat badan yang rendah. Keadaan ini disebabkan karena kurangnya suplai darah nutrisi akan oksigen pada plasenta yang akan berpengaruh pada fungsi plesenta terhadap janin. ${ }^{3}$ Pada penelitian ini terdapat sangat sedikit ibu yang mengalami jarak kehamilan yang berisiko dan menunjukkan hasil yang tidak bermakna terhadap BBLR. Hasil penelitian ini sesuai dengan studi Yuliani dkk dan Mahayana dkk dimana memperoleh hubungan yang tidak bermakna antara jarak kehamilan berisiko dengan kejadian BBLR., ${ }^{3,7}$

Kehamilan ganda yaitu kehamilan dimana jumlah janin yang dikandung lebih dari satu. Kehamilan ganda meningkatkan insidensi IUGR, kelainan kongenital dan presentasi abnormal. Berat badan janin pada kehamilan kembar lebih ringan dari pada janin pada kehamilan tunggal pada umur kehamilan yang sama. Berat badan janin pada kehamilan kembar rata-rata 1000gr lebih ringan dari pada janin kehamilan tunggal dan pada umumnya memiliki berat kurang dari 2.500 gram. $^{8}$ Hasil analisis resiko menunjukan bahwa Ibu dengan kehamilan ganda memiliki risiko melahirkan bayi BBLR 14,9 kali lebih tinggi dibandingkan ibu tanpa kehamilan ganda. Hasil ini sesuai dengan penelitian Makbruri di RS Muhammadiyah Palembang yang menyatakan terdapat hubungan yang bermakna antara gemeli/kehamilan ganda dengan kejadian BBLR. $^{8}$

Bayi yang lahir dalam keadaan prematur (umur gestasi<35) meningkatkan kemungkinan lahir dengan berat badan rendah. Oleh karena pertumbuhan janin yang belum sempurna di minggu-minggu akhir gestasi sehingga berat badan bayi menjadi rendah saat lahir.' Hasil analisis resiko juga menunjukkan hubungan yang bermakna antara bayi yang lahir prematur dengan kejadian BBLR dimana resikonya 3,1 kali lebih besar dibandingkan dengan bayi yang lahir cukup bulan (aterm). Penelitian ini sejalan dengan penelitian yang dilakukan oleh Kumalasari dkk di RSUP dr. Mohammad Hoesin Palembang. ${ }^{9}$

Aspek pekerjaan juga dinilai pada studi ini. Pekerjaan ibu menjadi salah satu perhatian penulis oleh karena aktivitas fisik berlebihan dari ibu yang bekerja di luar rumah yang mungkin dialami ibu yang sedang mengandung. Selain itu tingkat stress yang dialami ibu yang bekerja kantoran juga menurut penulis dapat mempengaruhi kesehatan bayi yang dikandungnya. ${ }^{4,6}$ Hipotesis awal penulis memperkirakan ibu hamil yang bekerja sebagai selain ibu rumah tangga (misalnya PNS atau Swasta) mungkin akan mengalami gangguan saat proses kehamilan sehingga akan mempengaruhi berat badan janin yang dikandungnya. Namun ternyata dalam penelitian ini tidak ditemukan hubungan yang bermakna antara pekerjaan ibu dengan kejadian BBLR. Hasil ini sejalan dengan penelitian yang dilakukan oleh Rini dkk dan Trihardiani dkk. 4,6

Dan yang terakhir, tingkat pendidikan ibu mengambarkan pengetahuan kesehatan. Seseorang yang memiliki pendidikan tinggi mempunyai kemungkinan pengetahuan tentang kesehatan juga tinggi, karena makin mudah memperoleh informasi yang didapatkan tentang kesehatan lebih 
banyak dibandingkan dengan yang berpendidikan rendah. Semakin tinggi pendidikan ibu akan semakin mampu mengambil keputusan bahwa pelayanan kesehatan selama hamil dapat mencegah gangguan sedini mungkin bagi ibu dan janinnya. Pendidikan juga sangat erat kaitannya dengan tingkat pengetahuan ibu tentang perawatan kehamilan dan gizi selama masa kehamilan. ${ }^{10}$ Pada penelitian ini tidak ditemukan hubungan yang bermakna antara pendidikan ibu dan kejadian BBLR. Hasil ini sesuai dengan penelitian yang dilakukan oleh Kristiana dkk sebelumnya namun bertentangan dengan hasil penelitian yang dilakukan oleh Rini dkk dan Kumalasari dkk. ${ }^{4,9,10}$

\section{SIMPULAN}

Hasil penelitian menunjukkan bahwa tidak terdapat hubungan bermakna antara faktor risiko umur ibu, paritas, jarak kehamilan, kadar $\mathrm{Hb}$, status gizi ibu, pekerjaan ibu dan pendidikan ibu dengan kejadian BBLR di UPT Kesmas Gianyar I. Akan tetapi, Ibu dengan kehamilan ganda memiliki risiko melahirkan bayi BBLR 14,9 kali lebih tinggi dibandingkan ibu tanpa kehamilan ganda. Begitupula dengan Ibu hamil yang melahirkan bayi prematur memiliki risiko melahirkan bayi BBLR 3,1 kali lebih tinggi dibandingkan dengan ibu yang melahirkan bayi aterm.

\section{ETIKA PENELITIAN}

Penelitian ini telah mendapatkan persetujuan etik dari Komisi Etik Fakultas Kedokteran Universitas Udayana, Bali, Indonesia sebelum penelitian berjalan.

\section{KONFLIK KEPENTINGAN}

Penulis menyatakan bahwa tidak terdapat konflik kepentingan dalam penulisan artikel penelitian ini.

\section{PENDANAAN}

Seluruh penulis bertangung jawab terhadap pendaan penelitian ini tanpa melibatkan pihak sponsor atau berbagai sumber pendanaan lainnya.

\section{KONTRIBUSI PENULIS}

Seluruh penulis bertanggung jawab dalam penulisan artikel penelitian ini mulai dari tahap penyusunan proposal, pengambilan data, analisis data penelitian, hingga interpretasi hasil penelitian yang ditampilkan dalam bentuk artikel publikasi.

\section{DAFTAR PUSTAKA}

1. Cha S. The impact of the worldwide Millennium Development Goals campaign on maternal and underfive child mortality reduction: 'Where did the worldwide campaign work most effectively?'. Glob Health Action. 2017;10(1):1267961.

2. Alya D. Faktor-Faktor yang Berhubungan dengan Bayi Berat Badan Lahir Rendah (BBLR) di Rumah Sakit Ibu dan Anak Banda Aceh Tahun 2013 [Skripsi]. Program Studi Diploma IV Kebidanan STIKes U’Budiyah Banda Aceh. 2014

3. Mahayana SAS, Chundrayetti E, Yulistini. Faktor Risiko yang Berpengaruh terhadap Kejadian Berat Badan Lahir Rendah di RSUP Dr. M. Djamil Padang. Andalas Journal of Health. 2015;4(3):664-73.

4. Rini SS, Windiani IGAT. Faktor-Faktor Risiko Kejadian Berat Bayi Lahir Rendah di Wilayah Kerja Unit Pelayanan Terpadu Kesmas Gianyar II. OJS Universitas Udayana. 2015;4(4):1-17.

5. Simbolon D, Aini N. Kehamilan Umur Remaja Prakondisi Dampak Status Gizi Terhadap Berat Lahir Bayi di Kabupaten Rejang Lebong Propinsi Bengkulu. [Skripsi] Program Sarjana Fakultas Kesehatan Masyarakat Universitas Jember. 2013.

6. Trihardiani I. Faktor Risiko Kejadian Berat Badan Lahir Rendah di Wilayah Kerja Puskesmas Singkawang Timur Dan Utara Kota Singkawang [Skripsi]. Program Sarjana Ilmu Gizi Fakultas Kedokteran Universitas Diponegoro; 2011.

7. Yuliani, Putra IWGAE, Windiani IGAT. Faktor Risiko Kejadian Bayi Berat Lahir Rendah di Rumah Sakit Umum Daerah dr.R.Soedjono Kabupaten Lombok Timur. Public Health and Preventive Medicine Archive. 2015;3(2):167-72

8. Makbruri. Faktor Risiko yang Memengaruhi Berat Badan Lahir Rendah dan Sangat Rendah di Kecamatan Seberang Ulu II Kota Palembang Periode 1 Januari-31 Desember 2008. Jurnal Gradien. 2015;11(1):1079-84

9. Kumalasari I, Tjekyan S, Zulkarnain M. Faktor Resiko dan Angka Kejadian Berat Badan Lahir Rendah (BBLR) Di RSUP Dr. Mohammad Hoesin Palembang Tahun 2014. Jurnal Ilmu Kesehatan Masyarakat. 2018;9(1):41-52

10. Kristiana N, Juliansyah E. Umur, Pendidikan, Pekerjaan Dan Pengetahuan Dengan Kejadian Berat Badan Lahir Rendah (BBLR). Wawasan Kesehatan. 2017;4(1):7-14

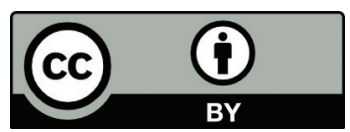

This work is licensed under a Creative Commons Attribution 